\title{
Total Phenol Content and Activities of Antioxidant Extracts Methanol Limes (Citrus Aurentifolia) By Uv-Vis Spectrophotometry
}

\author{
Khadijah ${ }^{1}$, Nunuk Hariani Soekamto ${ }^{2 *}$, Siti Maisuri Tadjuddin Chalid ${ }^{3}$, Nur Fatin Rafidah $^{4}$ \\ ${ }^{1}$ Chemistry Education Study Program, FKIP Khairun University, Ternate, Indonesia \\ ${ }^{2}$ Department of Chemistry, FMIPA, Hasanuddin University, Makassar, Indonesia \\ ${ }^{3}$ Department of Obstetrics and Gynecology, Faculty of Medicine, Hasanuddin University, Makassar, Indonesia \\ ${ }^{4}$ Student from Department of Chemistry, FMIPA, Hasanuddin University, Makassar, Indonesia
}

\begin{abstract}
Total phenol levels and antioxidant activity in whole limes from Palopo, Luwu Regency, as well as the relationship between total phenol content and antioxidant activity, were determined. Maceration of dried whole lime fruit yielded the methanol extract (Citrus aurentifolia). Phytochemical screening was used to determine the presence of alkaloids, phenolic compounds, and flavonoids in the extract's secondary metabolites. The total phenol extract was determined using the Folin-Ciocalteu method, yielding a value of $8.37 \mathrm{mgGAE} / \mathrm{g}$. Antioxidant activity was determined using the DPPH method, and the IC50 value was $1793.06 \mathrm{~g} / \mathrm{mL}$. Total phenol content of whole fruit extract lime and IC50 show a linear relationship $\mathrm{y}=$ $168,11 x+3211$ with a determination $\mathrm{R} 2=$ of 0.9780
\end{abstract}

Keywords: Uv-Vis Spectrophotometry, Antioxidant Activity, Phytochemical screening

\section{Introduction}

Because the human body only has a limited number of antioxidants, if there are a lot of radicals in the body, the body requires antioxidants from outside [1]. Natural antioxidants and artificial antioxidants are both sources of antioxidants, but the use of artificial antioxidants is currently being limited due to research findings that artificial (synthetic) antioxidants such as BHT (Butylated Hydroxy Toluene) can be toxic to experimental animals and carcinogenic.

The use of natural resources as a source of natural antioxidants is preferable because it produces fewer side effects than synthetic drugs, which frequently produce side effects that are more harmful to health. Furthermore, the economic crisis that several Asian countries, including Indonesia, experienced caused the price of synthetic drugs to expensive, reducing the public's access to synthetic drugs. An alternative treatment is the use of natural ingredients as traditional medicine and as a basic ingredient in medicine [2,3].

According to the findings of an ethnobotanical survey, lime (Citrus aurentifolia) is one of the fruits that is widely consumed as an addition to food and beverages in Indonesia. South Sulawesi, particularly Luwu Regency, is one of Makassar City's lime suppliers.

Lime, which belongs to the Rutaceae family, is a plant that grows well in areas with plenty of sunlight. Several previous studies on total phenols and antioxidants in orange juice [4,5] and orange peel [6-8] were conducted.

Investigation in this research It has never been done before, we determine the total phenol content and antioxidant activity of whole limes without separating the skin and juice. The public's use of lime fruit for extracting juice is based solely on experience and educated guesses.

Antioxidant compounds such as flavonoids, tannins, anthraquinones, cinnamates, and xanthones, have been proven to be used as immune enhancers $[9,10]$. Several previous studies have always separated between fruit juice and orange peel. This study was focused on knowing the total phenolic content and antioxidant activity of the methanol extract contained in the whole fruit of lime (Citrus aurentifolia) and the relationship between total phenolic and its antioxidant activity.

\section{Research methodology}

\subsection{Tools and materials}

A digital balance, a rotary evaporator, glassware, and a Shimadzu UV-1800 UV-VIS spectrophotometer were used in this study.

Whole lime fruit, methanol solution pa, DPPH, distilled water, cotton, aluminum foil, LB reagent, Meyer reagent, Dragendorf reagent, Folin-Ciocalteu

\footnotetext{
* Corresponding author : nunukhariani@unhas.ac.id
} 
solution, gallic acid, $\mathrm{Na} 2 \mathrm{CO} 3$, Magnesium, and Aquades were used in this study.

\subsection{Sample preparation}

Whole limes were obtained from the plantation in Palopo City, South Sulawesi. The samples were then cleaned, thinly sliced, and dried away from direct sunlight.

\subsubsection{Maceration and extraction}

The samples were then blended into powder in the Laboratory of Organic Chemistry, Faculty of Mathematics and Natural Sciences, Hasanuddin University, and macerated with methanol for $3 \times 24$ hours at room temperature. The methanol extract obtained was collected and evaporated using a rotary evaporator to obtain a thick methanol extract and then weighed, and then tested for the content of secondary metabolites, total phenolic and antioxidants.

\subsubsection{Identification}

The methanol extract from whole citrus fruit was screened for phytochemicals to determine the content of secondary metabolites in the form of alkaloids, flavonoids, phenolics, steroids and saponins, which were present in the whole lime fruit (Citrus aurentifolia) [11].

\subsubsection{Alkaloid test}

Carried out on the sample extract as much as $0.2 \mathrm{~g}$ added $5 \mathrm{ml}$ of $25 \%$ ammonia and then crushed with a mortar. Added $20 \mathrm{ml}$ of chloroform, ground again and filtered. The filtrate was put into a test tube, added $10 \% \mathrm{HCl}$ and then shaken. The upper solution (chloroform phase) was taken, then divided into two test tubes, each adding Dragendorff, Mayer and Wager reagents. If a brick red precipitate is formed with Dragendorff's reagent, a white precipitate with Mayer's reagent and a brown precipitate with Wagner's reagent indicates the presence of a group of alkaloid compounds.

\subsubsection{Flavonoid test}

Carried out on $0.2 \mathrm{~g}$ of sample extract, added $0.05 \mathrm{~g}$ of magnesium powder $(\mathrm{Mg})$ and $0.2 \mathrm{ml}$ of alcoholic acid (a mixture of $37 \% \mathrm{HCl}$ and $96 \%$ methanol with the same volume), then added $2 \mathrm{ml}$ of amyl alcohol. then shaken vigorously and allowed to separate. The formation of a red, yellow or orange color on the amyl alcohol layer indicates the presence of flavonoid compounds.

\subsubsection{Steroids and triterpenoids test}

Carried out on $0.2 \mathrm{~g}$ of sample extract, put in a loosecovered erlenmeyer, added $20 \mathrm{ml}$ of diethylether, and then filtered. A total of $5 \mathrm{ml}$ of the filtrate was evaporated in an evaporating dish to obtain a residue, then Liebermann-Burchard reagent was added. Formation of red or green color indicates the presence of steroid or triterpenoid compounds.

\subsubsection{Saponin test}

Carried out on $0.2 \mathrm{~g}$ of sample extract, added $100 \mathrm{ml}$ of hot water, boiled for 5 minutes, then filtered with filter paper (solution A). $10 \mathrm{ml}$ of solution A was put into a test tube and shaken vigorously vertically for 10 seconds. The formation of foam as high as 1-10 cm which is stable for 10 minutes and does not disappear with the addition of a drop of $2 \mathrm{~N} \mathrm{HCl}$, indicates the presence of saponin group compounds.

\subsubsection{Phenolic test}

Carried out by reacting the methanol extract of whole oranges and mulberry fruit (Morus alba L.) with $1 \%$ $\mathrm{FeCl}_{3}$ solution. The results are indicated by the formation of green, red, purple, dark blue, blue, blackish blue, or blackish green [12].

\subsubsection{Analysis of total phenolic}

\subsubsection{Determination of the maximum wavelength of gallic acid}

A mother liquor of $100 \mathrm{ppm}$ gallic acid was prepared by dissolving 0.01 grams of gallic acid in a $100 \mathrm{ml}$ volumetric flask, adding $1 \mathrm{ml}$ of methanol and then adding distilled water to the mark. The $100 \mathrm{ppm}$ mother liquor was then taken $1 \mathrm{ml}$ and put into a $10 \mathrm{ml}$ volumetric flask, added $1 \mathrm{ml}$ of Folin-Ciocalteu reagent, then shaken until homogeneous. Let stand for a few minutes then add $4 \mathrm{ml}$ of $\mathrm{Na}_{2} \mathrm{CO}_{3} 10 \%$, let stand for 15 minutes at room temperature. Furthermore, measurements were carried out with a visible spectrophotometer at a wavelength of 700 to $800 \mathrm{~nm}$ to determine the maximum wavelength.

\subsubsection{Making gallic acid calibration curve with Folin-Ciocalteu reagent}

The mother liquor of $100 \mathrm{ppm}$ gallic acid was taken 1 $\mathrm{ml}$ each; $3 \mathrm{ml} ; 5 \mathrm{ml} ; 7 \mathrm{ml}$. Then diluted with distilled water to a final volume of $10 \mathrm{ml}$ to obtain a solution with a concentration of $10 \mathrm{ppm} ; 30 \mathrm{ppm} ; 50 \mathrm{ppm} ; 70 \mathrm{ppm}$. $0.2 \mathrm{ml}$ of each concentration was pipetted and then put into a $10 \mathrm{ml}$ volumetric flask, added $1 \mathrm{ml}$ of FolinCiocalteu reagent and shaken until homogeneous, allowed to stand for 8 minutes. Added $3 \mathrm{ml}$ of $\mathrm{Na}_{2} \mathrm{CO}_{3}$ $10 \%$ then shaken homogeneously, and then let stand for 30 minutes at room temperature. Measure the maximum absorption wavelength of $\mathrm{nm}$, then a calibration curve is made using the regression equation $\mathrm{y}=\mathrm{bx}+\mathrm{a}$. 


\subsubsection{Determination of total phenol content by Folin-Ciocalteu method}

Pipette $0.2 \mathrm{ml}$ of extract, add $15.8 \mathrm{ml}$ of distilled water and $1 \mathrm{ml}$ of Folin-Ciocalteu reagent then shaken. Let stand for 8 minutes then add $3 \mathrm{ml}$ of $\mathrm{Na}_{2} \mathrm{CO}_{3} 10 \%$ to the mixture. Leave the solution for 1 hour at room temperature. The absorption was measured using a UVVis spectrophotometer at the maximum wavelength. It was repeated three times so that the phenol content obtained was obtained as $\mathrm{mg}$ gallic acid equivalent/g fresh sample.

\subsubsection{Analysis of Total Phenolic}

Activity was analyzed first by making a solution of DPPH (1,1-diphenyl-2-phikril-hydrazil) by dissolving DPPH crystals into methanol at a concentration of 0.01 $\mathrm{M}$ and adding methanol to a volume of $5 \mathrm{ml}$, then measuring the absorbance at a length of $517 \mathrm{~nm}$ wave as control absorbance. The next process is the measurement of sample absorbance from extraction with n-hexane solvent. Measure the absorbance of the sample by taking $200 \mathrm{mg}$ of the sample and dissolving it in $5 \mathrm{ml}$ of mmethanol while vortexing for 1 hour. Then, take $1 \mathrm{ml}$ of the mixture and add $1 \mathrm{ml}$ of $0.01 \mathrm{M}$ $\mathrm{DPPH}$ and mmethanol until the volume is $5 \mathrm{ml}$. Then the absorbance of the sample was measured at a wavelength of $517 \mathrm{~nm}$. Repeating the absorbance analysis of the samples extracted with chloroform and ethyl acetate as solvents. The absorbance data of the samples obtained were used to determine the Inhibition Concentration (IC) (\%). Inhibition Concentration $\left(\mathrm{IC}_{50}\right) \quad(\%)$ is calculated by the equation:

$$
\% \text { Inhibition }=\frac{\left(A_{\text {control }}-A_{\text {sample }}\right)}{A_{\text {control }}} \times 100
$$

Note: $\mathrm{A}_{\text {control }}=$ Absorbance does not contain sample $\mathrm{A}_{\text {sample }}=$ Absorbance sample

\section{Results and discussion}

\subsection{Phytochemical Analysis}

The results are presented in Table 1.

Table 1. Phytochemical test of lime extract (Citrus aurentifolia).

\begin{tabular}{|c|l|c|c|}
\hline $\begin{array}{c}\text { No } \\
\cdot\end{array}$ & $\begin{array}{c}\text { Phytochemical } \\
\text { test }\end{array}$ & $\begin{array}{c}\text { Result } \\
\text { test }\end{array}$ & $\begin{array}{c}\text { Indicator } \\
\text { Changed }\end{array}$ \\
\hline 1 & Alkaloid & & \\
\hline & a. Dragendorff & ++ & Dark orenge \\
\hline & b. mayer & + & Yellow \\
\hline 2 & Flavonoid & & \\
\hline & a. timbal asetat & + & White sediment \\
\hline & b. Mg & - & \\
\hline 3 & Teroenoid & - & \\
\hline 4 & Fenolik & +++ & Dark green \\
\hline 5 & Saponin & - & \\
\hline
\end{tabular}

Note: (-) : negative; $(+)$ : positive but weak; $(++)$ : Strong positive; $(+++)$ : Positive and very strong
The methanol extract of whole lime fruit was analyzed for its chemical compound content by color test using several reagents. This test was conducted to determine the presence of flavonoid, phenolic, alkaloid, steroid/terpenoid, and saponin compounds. These compounds determine the characteristics of active compounds that cause toxic effects or beneficial effects, which are shown by crude plant extracts tested with biological systems [12]. The test results can be seen in Table 1.

\subsubsection{Flavanoid test}

Analysis of whole lime fruit samples extracted with methanol solvent and it was found that the tested samples contained flavonoid compounds. Flavonoid compounds are polar compounds because they have an unsubstituted hydroxyl group (-OH) so that hydrogen bonds can form. The presence of flavonoid compounds in the test results is due to the fact that some terpenoid compounds have a cyclic structure in the form of alcohol which causes these compounds to tend to be semipolar so that their bond with polar solvent methanol is very weak [12]. This is indicated by two different tests, only one of which was identified as containing flavonoids (Table 1).

\subsubsection{Alkaloid test}

Analysis of whole lime fruit samples extracted with methanol solvent and it was found that the samples tested all contained alkaloid compounds. The principle of this analytical method is the precipitation reaction and color changes that occur due to ligand replacement. The nitrogen atom which has a lone pair of electrons in the alkaloid compound can replace the Bi ion in the Mayer reagent. Nitrogen as part of its cyclic system in alkaloid compounds has varied substituents such as amine, amide, phenol and methoxy groups so that it is semipolar [13]. While Dragendorf's reagent contains potassium iodide and mercury (II) chloride will react to form a red precipitate of mercury (II) iodide. If too much potassium iodide is added, potassium tetraiodomercurate (II) is formed. In the alkaloid test with Mayer's reagent there will be a reaction between nitrogen and potassium ions $(\mathrm{K}+)$ to formpotassium alkaloid complex a precipitated [14]. Alkaloid compounds have the effect of triggering the nervous system, raising blood pressure, reducing pain, antimicrobial, sedative, heart disease medication and antidiabetic.

\subsubsection{Steroid/triterpenoid test}

Analysis of whole lime fruit samples extracted with methanol solvent and it was found that the tested samples did not contain terpenoids or steroids. This analysis is based on the ability of steroid and terpenoid compounds to form colors by concentrated sulfuric acid previously dissolved in chloroform, the absence of terpenoid or steroid compounds in the test results is due 
to the fact that some terpenoid compounds have a cyclic structure in the form of alcohol which causes these compounds to tend to be semipolar. so that the bond with the polar solvent methanol is very weak. Steroids have a terpenoid base framework that forms aring prehydrophenanthrene cyclopentane.

\subsubsection{Saponin test}

Analysis of whole lime fruit samples extracted with methanol solvent and it was found that the tested samples did not form foam in the test results.

\subsubsection{Phenolic test}

Analysis of the content of phenolic compounds in the methanol extract of the whole lime fruit showed that there were phenolic compounds in the whole lime fruit extract, this is an indication to further explore the total phenolic content of this whole lime fruit extract. Phenolics have an aromatic ring with one or more hydroxyl groups $(-\mathrm{OH})$ and other accompanying groups. The largest group of phenolic compounds is flavonoids, this is confirmed in the phytochemical test of the flavonoid compound group in the whole lime fruit from Palopo City. Phenolic compounds that may exist are phenolic compounds such as monocyclic phenols, phenyl propanoids, polyphenols (lignin, melanin, tannins), and phenolic quinones.

\subsection{Analysis of total phenol levels}

Result of Total Phenol Levels

Table 2. Data of absorbance measurement data standard gallic acid

\begin{tabular}{|c|c|}
\hline [Asam Galat] $(\mathbf{m g} / \mathbf{m L})$ & Absorbansi \\
\hline 0,001 & 0,110 \\
\hline 0,002 & 0,213 \\
\hline 0,004 & 0,426 \\
\hline 0,008 & 0,825 \\
\hline 0,016 & 1,660 \\
\hline
\end{tabular}

Test Determination of the total phenol content of the whole fruit of lime was carried out using the FolinCiocalteu method. The principle of the Folin-Ciocalteu method is the oxidation of phenolic hydroxyl groups. This reagent oxidizes phenolics (alkali salts), reducing heteropoly acids to a molybdenum-tungsten (Mo-W) complex. Phenolates are only found in basic solutions, but the Folin-Ciocalteu reagent and its products are unstable under basic conditions. During the reaction, the phenolic-hydroxyl group reacts with the Folin-Ciocalteu reagent, forming a blue phosphotungstatephosphomolybdate complex with an unknown structure that can be detected by a spectrophotometer. The blue color formed will be more concentrated equal to the concentration of phenolic ions formed, meaning that the greater the concentration of phenolic compounds, the more phenolic ions will reduce heteropoly acids so that the resulting blue color is more concentrated [15].

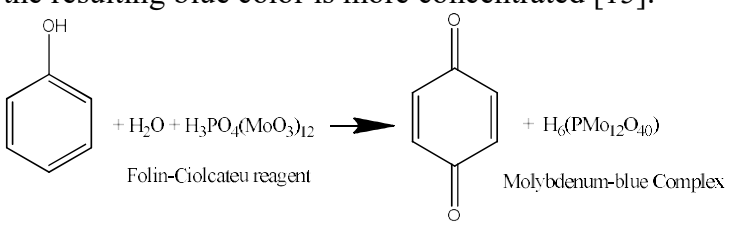

Fig. 1. Reaction of phenol compounds with Folin-Ciocalteu reagent

Data Results Measurement of total phenolic concentration of whole lime fruit extract is 8,37 $\mathrm{mgGAE} / \mathrm{g}$, which means that in one gram of extract there is $8.37 \mathrm{mg}$ of phenolic compounds. The total phenol content was obtained from the linear regression equation $\mathrm{y}=103.15 \mathrm{x}+0.0072$, with $\mathrm{R}^{2}=0.9999$ as shown in Figure 2, the relationship between absorbance and gallic acid standards at various concentrations. This difference is based on the fact that the total phenol content in whole limes is largely determined by fruit conditions, soil conditions, application of fertilizers and environmental conditions both biologically, physically, and chemically [16].

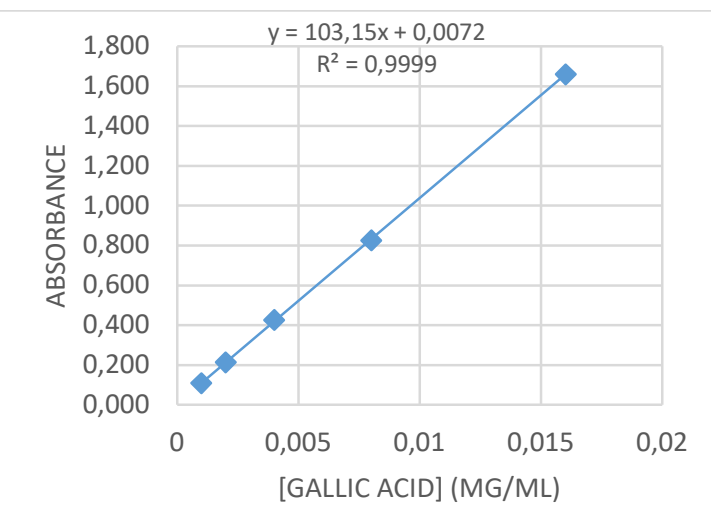

Fig. 2. The relationship between absorbance and gallic acid concentration in the determination of total phenolic methanol extract of lime (citrus aurentifolia)

\subsection{Antioxidant activity test antioxidant}

Activity test showed that lime methanol extract contained antioxidant activity. Whole lime fruit (a mixture of juice and skin) has a higher $\mathrm{IC}_{50}$ value, unlike the previously reported by Permata et al, 2018 where the reported $\mathrm{IC}_{50}$ was $49,589 \mathrm{~g} / \mathrm{mL}$ for the juice and 187.36 ppm for the peel. Citrus lime (citrushystrix DC) by Sari and Ayati, 2018, where the lower the value of $\mathrm{IC}_{50}$ samples showed the ability of its high antioxidant activity. This is also confirmed by the results of the determination of the total phenol content of the extract. Antioxidant activity data are presented in table 3 below. 
Table 3. Percentage of DPPH attenuation in methanol extract of whole fruit of Lime (Citrus aurantiifolia)

\begin{tabular}{|c|c|c|c|c|}
\hline No. & $\begin{array}{c}\text { Concentr } \\
\text { ation } \\
(\mu \mathrm{g} / \mathrm{mL})\end{array}$ & $\begin{array}{c}\text { Absorban } \\
\text { ce (A) } \\
\lambda=515 \\
\text { nm }\end{array}$ & $\begin{array}{l}\text { Antioxida } \\
\text { nt } \\
\text { Activity } \\
(\%) \\
\end{array}$ & $\begin{array}{c}\text { IC-50 } \\
(\mu \mathrm{g} / \mathrm{mL})\end{array}$ \\
\hline 1 & 200 & 0,480 & 13,51 & \multirow{5}{*}{$1793,06^{*}$} \\
\hline 2 & 400 & 0,430 & 22,52 & \\
\hline 3 & 800 & 0,380 & 31,53 & \\
\hline 4 & 1600 & 0,290 & 47,75 & \\
\hline 5 & 3200 & 0,124 & 77,66 & \\
\hline 6 & kontrol & 0,555 & & \\
\hline
\end{tabular}

*with three times repetition

After knowing the percent antioxidant activity of lime leaf extract, then the $\mathrm{IC}_{50}$ value can be determined, namely the concentration required to reduce DPPH by $50 \%$. The $\mathrm{IC}_{50}$ value can be determined by the linear regression equation (Figure 3 ).

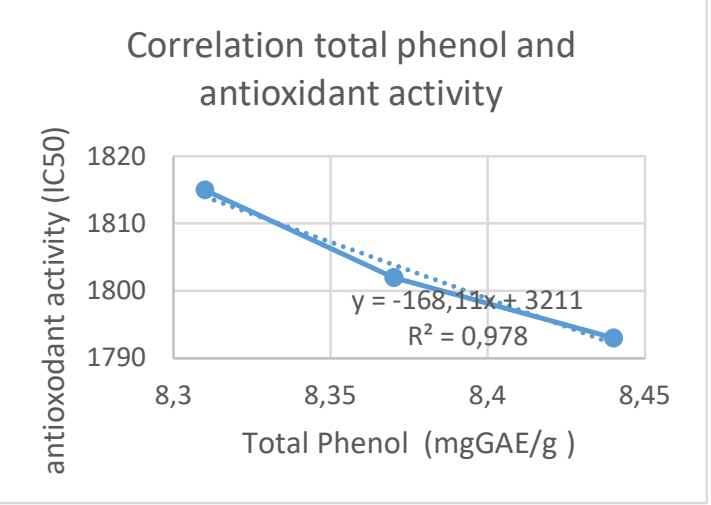

Fig. 3. Graph of Correlation between total phenol and antioxidant activity of methanol extract of whole lime (citrus aurentifolia) fruit.

The smaller the IC50 value obtained, the higher the strength of a compound that is an antioxidant to fight the effectiveness of DPPH as a free radical[17] According to [18] measured the antioxidant activity of IC50 values are presented in Table 4.

Table 4. IC 50 value of antioxidant activity

\begin{tabular}{|c|c|}
\hline Antioxidant Activity & Value of $\mathrm{IC}_{50}$ \\
\hline Very strong & $<50 \mu \mathrm{g} / \mathrm{mL}$ \\
\hline Stronger & $50-100 \mu \mathrm{g} / \mathrm{mL}$ \\
\hline Was weak & $100-200 \mu \mathrm{g} / \mathrm{mL}$ \\
\hline Weak & $>200 \mu \mathrm{g} / \mathrm{mL}$ \\
\hline
\end{tabular}

So it can be concluded that the antioxidant activity of the methanol extract of the whole lime fruit is 1793.06 $\mathrm{g} / \mathrm{mL}$ which is very weak, this is probably due to the condition of the sample used according to [19] antioxidant stability can be influenced by factors such as temperature, changes in $\mathrm{pH}$, sunlight and oxygen. In addition, the analysis process also affects such as the storage period of the sample causing the phenol compounds thought to be contained in it to degrade, another is that the nutrient content in plants also affects the antioxidant content.

In general, compounds with a strong level of antioxidant activity are phenol group compounds which have a hydroxy group substituted on the benzene ring with ortho and para positions to the $-\mathrm{OH}$ and $-\mathrm{OR}$ groups. The phenol group of compounds can counteract free radicals by donating their protons so that they can form stable radicals with resonance in the aromatic ring which results in electron delocalization of the free electrons. This is also supported by phytochemical testing on whole citrus fruits which contain strong phenolic compounds but contain little flavonoids [20]

The correlation between total phenol and its antioxidant activity $\left(\mathrm{IC}_{50}\right)$ was $8.37 \mathrm{mgGAE} / \mathrm{g}$ for the total phenol content and $1793.06 \mathrm{~g} / \mathrm{mL}$ for its antioxidant activity. As presented in Figure 3 below:

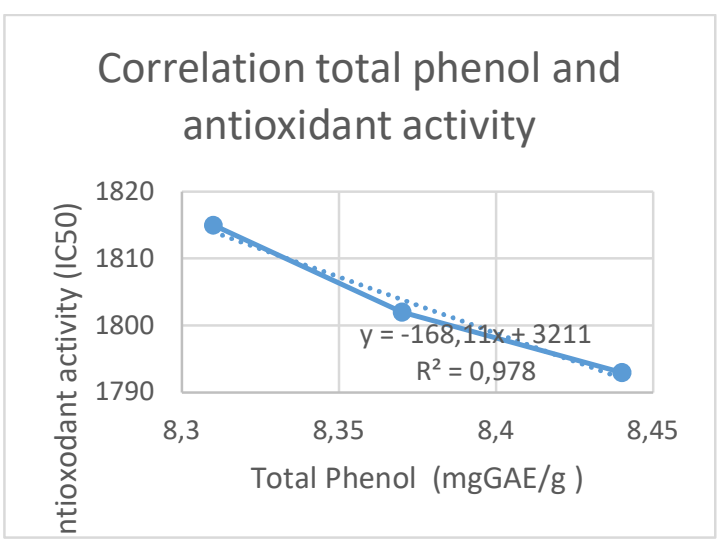

Fig.4. Graph of Correlation between total phenol and antioxidant activity of methanol extract of whole lime (citrus aurentiifolia) fruit

This shows that $97.8 \%$ of antioxidant activity is influenced by the contribution of phenolic compounds $[20,21]$. This is also in line with several previous studies which stated that the total phenol content was directly proportional to the antioxidant activity of a material [22].

\section{Conclusion}

1. Secondary metabolic compounds detected after phytochemical tests were alkaloids, phenolics and flavonoids.

2. The total content of phenol and $\mathrm{IC}_{50}$ in the whole fruit extract of lime (citrus aurentiifolia) is 8.37 $\mathrm{mgGAE} / \mathrm{g}$ and $1793.06 \mathrm{~g} / \mathrm{mL}$ in the very weak category. 
3. There is a relationship between the total phenolic content of the antioxidant activity of a material with a correlation coefficient of $97.8 \%$.

\section{References}

1. K Sayuti., R Yenrina, Antioksidan Alami dan Sintetik, Andalas University Press, Padang, Indonesia (2015)

2. Rahmaniar, Produk Alam Laut Sebagai Lead Compound untuk Farmasi dan Pertanian. Seminar Perspektif Baru dalam Drug Discovery. Ujung Pandang 26 Oktober 1996

3. A. E Nugroho, Biodiversitas $7,4: 378-382$ (2006)

4. A. Permata., A. Kurniawati., \& B. Lukiati. Jurnal Ilmiah Ibnu Sina, 3(1), 64 - 76 (2018)

5. S. Hindun, T. Rusdiana., M. Abdasah, R Hindritiani ; Indonesian Journal of Pharmaceutical Science and Technology, 4, 2 (2017)

6. A. Rauf., U. Pato., D.W. Ayu, J. Faperta 4 (2): 112 (2017)

7. A. K. Sari, R. Ayati, Journal of Current Pharmaceutical Sciences, 1, 2 (2018)

8. Purwaningsih, S. Jurnal Ilmu Kelautan, 17 (1) 3948 (2012)

9. Ministry of Health RI, Farmakope Indonesia (1995)

10. J. B Harborne. Metode Fitokimia: Penuntun Cara Modern Menganalisis Tumbuhan, diterjemahkan oleh Kosasih Padmawinata \& Iwang Soediro. Penerbit ITB, Bandung (1987).

11. J.B. Harbone Metode Fitokimia : Penuntun Cara Modern Menganalisis Tumbuhan. Edisi Kedua. Bandung : Penerbit ITB. pp 4-147.(2006)

12 RD. Purba, Analisis Komposisi Alkaloid Daun Handeuleum (Graptophyllum pictum (Linn), Griff) yang Dibudidayakan dengan Taraf Nitrogen yang Berbeda (Skripsi). Bogor : Institut Pertanian Bogor (2001).

13. S. Atun, Pengembangan Potensi Bahan Alam sebagai Sumber Penemuan Obat Baru. Makalah disajikan dalam Seminar Nasional Kimia, Universitas Negeri Yogyakarta, Yogyakarta, 24 September 2005

14. V.I. Singleton and J. JA. Rossi, American Journal of Enology and Viticulture. 16(3) (1964)

15. Kahkonen MP, Hopia AI, Heinonen. J Agri Food Chem. 49 : 9348-9 (2001)

16. Fajarwati, N. Uji Aktivitas Antioksidan Pada Ekstrak Daun Jeruk Nipis (Citrus aurantifolia) dengan Menggunakan Metode DPPH (1,1Dhipenyl -2- Picrylhydrazyl). Jakarta : UIN Syarif Hidayatullah. (skripsi) (2013)

17. Molyneux, P. The Use of The Stable Free Radical Dyhenylpicrylhydrazil (DPPH) For Estimating Antioxidant Activity. Journals science and technology: 26 :211-219. (2004)

18. Handayani, H. Uji Aktivitas Antioksidan Ekstrak Kulit Buah Naga (Hylocereus Poyhizus) Dengan Metode DPPH (1,1- Diphenyl-2-Picrylhydrazyl,
Karya Tulis Ilmiah, Akademi Farmasi ISFI Banjarmasin, Banjarmasin ((2016).

19. Rudiansyah, Aktivitas Pengawetan Fraksi Etil asetat Buah Asam kandis (G. Dioica Blum) Terhadap Tingkat Kesegaran Ikan Nila (Oreochromis niloticus). (Skripsi). (2012)

20. Javanmardi, J., Stushnoff, C., Locke, E. dan Vivanco, J.M. Journal of Food Chemistr 83 : 547 550 (2003).

21. K Khadijah., A. Jayali, S. Umar, dan I. Sasmita, Jurnal Kimia Mulawarman, 15(1), 11-18. (2017)

22. Huang GL, Wang BJ, Weng YM. $J$ food processing and preservation. 10 : 1745-4549.( 2012) 